\title{
The Influence of Leadership and Work Motivation on Teacher Performance
}

\author{
Winarty Sudarman ${ }^{1 *}$, Syaiful Eddy², Bukman Lian ${ }^{2}$ \\ ${ }^{1}$ SD Negeri 2 Sri Gunung, Palembang, Indonesia \\ ${ }^{2}$ Universitas PGRI Palembang, Indonesia \\ *Corresponding author. E-mail: winartysudarman@gmail.com
}

\begin{abstract}
This study aims to determine the effect of principal leadership and teacher work motivation on teacher performance. This type of research is quantitative. Data obtained by survey method, namely by distributing questionnaires as a research instrument. This research was conducted at SDN Sungai Lilin, Musi Banyuasin District, Indonesia. The research sample was 49 teachers. Data were analyzed using correlational analysis techniques and multiple regression. The results of the study concluded: (1) there is a significant influence of principal leadership on teacher performance; (2) there is an effect of teacher work motivation on teacher performance; and (3) there is a joint influence of principal leadership and teacher work motivation on teacher performance.
\end{abstract}

Keywords: leadership, motivation, teacher performance

\section{INTRODUCTION}

This research is motivated by the facts that the researchers found in the field. The observation result shows that the teacher's performance is still not optimal. This can be seen from several phenomena that the researchers found in the field, including learning planning that has not been made optimally because learning plans and learning tools still exist using copy paste culture, in the implementation of learning some teachers have not used various media and relevant learning sources, in implementation. learning some teachers still dominantly use conventional methods, and classroom teacher administration is not yet fully structured.

The mandate of the noble ideals of the Indonesian nation as stated in the Preamble to the 1945 Constitution is to educate the nation's life. These ideals can be realized by holding national development in various fields. Development of the education sector can be used as the main sector because it is oriented towards improving the quality of human resources to develop a complete Indonesian human being.

This is stated in Law Number 20 of 2003 which describes the national education system. An intelligent and dignified national life is the main goal of the national education system. With the implementation of the national education system, it is hoped that it will be able to develop and shape the character and civilization of the nation. This national education system becomes the foundation and hope for students who have faith and devotion to God Almighty, physically and mentally healthy, have noble character, increase the spirit of independence, are smart, creative and innovative, and have a sense of responsibility as citizens. democratic country.

Competent human resources who have personality and high motivation will support the achievement of national education goals [1]. A series in achieving organizational goals is the existence of various activities that are the most essential part of the human resource management process [2]. Improving the quality of teaching staff is very important to be carried out regularly and continuously. As explained in the Decree of the Minister of State Apparatus Empowerment Number 84 of 1993, that teachers are state civil servants who carry out the main task of teaching and guiding students starting from childhood, primary and secondary education. This main task must be carried out responsibly in accordance with the rights and authorities given by the government. The main personnel at school are teachers. Schools and communities make teachers at the forefront of all activities, including national education and teaching. Efforts to involve teacher motivation and quality are indispensable for human resource development.

Teacher performance has a very important position in the context of improving and controlling the quality of education [3]. Teachers are required to be professional. The criteria for a position referred to as professional are positions that involve intellectual activities, study a more specific field of science, professional preparation, continuous job training, permanent employment, work standards, main services, and have a professional organization. Until now, teacher performance is still a problem that 
requires attention. Some of the causes are low discipline, lack of teacher mastery of subject matter, and not optimal teacher teaching methods [3]. The professional quality and competence of teachers have not met the standards. The development of students' abilities is deemed not optimal and intact.

Motivation can also be categorized as a factor that affects teacher performance [4]. Work motivation is an activity to give strength or encouragement to someone who can lead to behavior to carry out an activity according to the goals to be achieved. In addition to work motivation factors, teacher performance is also influenced by the leadership of the principal [4]. Leadership is an activity to influence people (subordinates) for the sake of striving hard to achieve group goals, in this case the success of educational goals.

Teacher achievement or performance can be influenced by several variables, including school leadership and teacher work motivation [5]. A school principal must have the knowledge and ability to create a conducive work atmosphere that can lead to teacher work motivation. The principal is expected to be a good reflection for the teachers as their subordinates so that the achievements or performance of teachers can grow and develop well too.

This means that the leadership of the principal has a very important role for the performance of teachers to carry out their duties properly in order to achieve maximum educational goals. This is evident from the results of Murniyati's [6] research which concluded that in her research there was a significant influence between principal leadership and work motivation on teacher performance. In addition, the results of research conducted by Fitriani [7] concluded that principal leadership has a significant effect on teacher performance. This means that the leadership of the principal can explain the amount of teacher performance in the school.

Optimal teacher performance greatly determines the quality of education. Performance is the end result of a person, potential, and special scope areas collected collectively to get something both visible results and services that are not directly visible [6], [7]. Performance is an achievement obtained from the field of work which is then applied in its performance so as to produce satisfactory results. This means that a teacher can improve their performance to maintain the stability of motivation in themselves on an ongoing basis [6], [7].

Some of the goals of teacher performance are being able and adept at doing new assignments to improve performance results and activities, target performance improvement activities, proficiency or improvement in attitudes towards coworkers with one performance activity, proficiency of new knowledge which will help teachers with solving complex problems over activity makes decisions on assignments. In the world of education, there are many collaborative efforts of a number of people to achieve a desired goal. In order to achieve that goal in every educational institution there is a leader. Leaders in educational institutions are usually referred to as school principals. As for educational leadership, it cannot be separated from leadership in general.

Leadership in an educational environment is related to the ability of a school principal to improve teacher performance. The principal must be able to create a positive culture so that teachers and all staff in schools understand more and are highly dedicated to improving school quality [8]. In other words, the principal is the main key in shaping the school culture. Principal leadership is related to a person's ability to lead a school professionally so that all available resources can be maximally empowered to achieve shared goals. Increasing the quality of education cannot be separated from the role of the principal because the principal is one of the main components of education.

The principal as the education leader in the school must have abilities and skills that can be practiced in everyday life at school. The behavior of a leader will be influenced by their background knowledge, values and experiences (the strength of the leader) [8]. For example, leaders who believe that individual needs must be secondary to the needs of the organization, may take a very important role in the activities of their subordinates. The way the principal interacts with subordinates greatly influences the success or failure of the school he leads.

The principal is someone who is appointed as a formal leader, in an organization in this case a school, a school principal who has duties and responsibilities towards superiors, subordinates and the work environment, and carries out his obligations as an educator, administrator and creator of the work climate in order to achieve goals which have been set. Adler [9] stated that the quality of teaching and learning that goes in a school is largely determined by the quality of principals leadership. Furthermore, the principal is someone who is given the authority and responsibility to optimally empower all the potential that exists in the school to achieve goals. Principals are required to have skills and intellectuals that can be demonstrated in everyday life.

The ability and skills of school principals are highly dependent on several areas of management work. The principal's work and duties are as a leader in the fields of curriculum, personnel, school and community relations, teacher and student relations, non-teaching personnel, relationships with other agencies, articulation with other schools, service management, homes, schools and equipment.

Mulyasa [10] stated that the principal is one of the components of education that is very instrumental in improving teacher performance. The school principal must be able and responsible for the implementation of all educational activities, which include learning activities, school administration, fostering education personnel, using and maintaining 
facilities and infrastructure in schools. Therefore, the principal must be professional in carrying out his leadership duties to improve teacher performance.

Kemdikbud [11] states that the principal is required to be able to determine the direction of development, harmonize relationships in work, and increase motivation. In fact, the role of the principal can affect the high or low performance of teachers. A leader is required to be able to arouse the desires and feelings of subordinates so as not to feel burdened or forced, and not to feel afraid in carrying out their duties.

The character of the principal as a leader will appear in various characteristics such as honesty, confidence, responsibility, risk-taking, big-hearted, stable emotions, and exemplary. The principal is the energy, the direction of school policy, which establishes methods for realizing both school goals in particular and educational goals in general.

Based on the description above it can be concluded that principal leadership is a process carried out by a leader of a school to influence, encourage, mobilize, and organize people or groups of people, think and act consistently, can make effective and efficient decisions, use and improve. potential resources for improving the quality of education in schools.

Thus, good leadership greatly affects the achievement or failure of organizational goals. A leader has an influence on the performance he leads, in this case the teacher's performance. Principal leadership has an influence on teacher performance, in other words, teacher performance cannot be separated from the influence of the principal's leadership. The better the leadership of the principal, the more it will improve the performance of teachers in carrying out their duties as educators.

Motivation comes from the Latin word movere which means to move forward. Motivation is something that encourages someone to show certain behavior [12]. The work motivation of a teacher is divided into two forms, namely intrinsic motivation which is motivation from within the teacher himself, in the form of awareness of the importance of the work he is doing. This is often referred to as pure motivation. For example, workers who are dedicated solely because they feel they have the opportunity to realize their full self-realization. Meanwhile, extrinsic motivation is motivation that arises due to factors that come from the outside environment.

Work motivation is an atmosphere that can motivate, arouse, maintain, and direct teacher behavior in working in their environment to achieve personal and organizational goals. Whereas a leader means someone who has skills in his personality and can influence members of the group he leads. This influence is directed to subordinates in order to achieve certain goals. Motivation in individuals is divided into 2 types, namely positive motivation and negative motivation [12]. Positive motivation is the process of influencing other people to want to do something they want. Meanwhile, negative motivation is the process of influencing others by using the power of power to frighten subordinates, so that subordinates carry out their duties.

Good leadership and good motivation will create a good working climate in an organization, in this case schools [12], [13]. Teachers are required to have high motivation and commitment in cultivating their profession as teaching staff so that they can reach the ideal level. Having the soul of an ideal teaching force is the hope of educational institutions in this country. Therefore, teachers who have an ideal spirit can emphasize the dimensions of their motivation at work.

\section{METHODS}

This study uses a quantitative approach with a survey method, namely by asking a series of questions to get respondents' answers. This study aims to see the influence between one variable and another. This study is an ex-post-facto study, because the researcher did not manipulate the state of the existing variables and directly looked for the existence and level of relationship of the variables reflected in the correlation coefficient [14], [15].

The quantitative research variables tested in this study were: (1) principal leadership (X1) on teacher performance (Y); teacher work motivation (X2) on teacher performance (Y); while testing the hypothesis together (simultaneously), namely the principal's leadership (X1) and work motivation (X2) on teacher performance $(\mathrm{Y})$, then all the data obtained were processed and processed with quantitative analysis.

The research sample was 49 teachers from the total number of teachers. The data collection technique in this study was a questionnaire. Questionnaire is a data collection method that is carried out by giving a set of questions / written statements to respondents to respond according to user requests.

The questionnaire used is a closed and scaled questionnaire, namely a questionnaire that has provided a statement so that the respondent only has to fill in the answers by giving a checklist with alternative answers. The data analysis technique used in this research includes data analysis using descriptive statistics and data analysis using inferential statistics. Based on the results of data collection from the distribution of questionnaires, then descriptively analyzed using the IBM SPSS Statistics 25 program.

\subsection{Partial Hypothesis Testing Criteria}

Partial test uses simple linear regression and is continued with the $t$ test through the SPSS version 25 program which aims to test whether each independent variable, namely the leadership of the principal (X1), and work motivation (X2) have a significant effect on the dependent variable, namely teacher performance 
(Y) partially. Simple Linear Regression, to determine whether there is a partial influence between the independent variables on the dependent variable. The statistical test in this simple linear regression is the $t$ test.

Partial hypothesis testing in this study uses the t test through the IBM SPSS Statistics 25 program. The results of the $t$ test data acquisition will be the basis for making decisions whether or not the first and second hypotheses in this study are accepted. Hypothesis testing criteria, namely if the probability value (Sig.) $>$ A (0.05) then Ho is accepted, or if the probability value (Sig.) $<\mathrm{A}(0.05)$ then Ho is rejected; or if tcount $>t_{\alpha(0.05)}$ then Ho is accepted, or if the value of $\mathrm{t}<\mathrm{t}_{\alpha(0.05)}$ then Ho was rejected [16], [17].

The coefficient of determination is used to test the effectindependent variable on the dependent variable. If this test is through SPSS, The coefficient of determination can be seen in the Model Summary output column of $\mathrm{R}$ Square when calculating the regression. While the test carried out to calculate the determinant coefficient can use the formula:

$K D=r^{2} \times 100 \% ;$ with $r^{2}=\frac{b \Sigma x y}{\Sigma y^{2}}$

Information :

KD : The coefficient of termination

r2 : Correlation coefficient

\subsection{Simultaneous Hypothesis Testing Criteria}

Simultaneous test using multiple linear regression and followed by the $\mathrm{F}$ test through the IBM SPSS Statistics 25 program. The $F$ test aims to determine the effect of the independent variables (principal leadership and teacher work motivation) together on the dependent variable (teacher performance). Multiple Linear Regression, to determine whether there is an influence of the principal's leadership and teacher work motivation on teacher performance. Hypothesis testing criteria, namely if FSig $>\alpha(0.05)$ then Ho is accepted, or if FSig $<\alpha(0.05)$ then $\mathrm{Ho}$ is rejected [16], [17]. To calculate the simultaneous test manually analyzed using the formula:

$F_{\text {hit }}=\frac{R^{2}(n-m-1)}{m \cdot\left(1-R^{2}\right)}$

Information:

R2 : Correlation value

n : Number of samples

m : Number of independent variables

R2 value is obtained from: $\left(R x_{1}, x_{2} y\right)=$ $\sqrt{\frac{b_{1} \Sigma x_{1} y+b_{2} \Sigma x_{2} y}{\Sigma y^{2}}}$.
Hypothesis testing criteria, namely if Fcount $>$ Ftable then Ho is accepted, or if Fcount $<$ Ftable then Ho is rejected.This determinant coefficient aims to test for the greatest influence the independent variable (principal leadership and teacher work motivation) on the dependent variable (teacher performance). NThe coefficient of determination can be seen in the RSquare column Model Summary output when calculating regression [16], [17].

\section{RESULTS AND DISCUSSION \\ 3.1 Effect of Principal Leadership on Teacher Performance}

The results of data analysis in this study indicate that partially the principal's leadership has a significant effect on teacher performance. This can be seen from the data listed in the descriptive statistics table showing the mean (average) value of 121.47. The highest score is 131 and the lowest score is 108 . From these results, the category is quite good as indicated by the leadership of the principal.

Table 1 Results of Hypothesis Analysis 1

\begin{tabular}{|c|c|c|c|c|c|c|}
\hline \multicolumn{7}{|c|}{ Coefficientsa } \\
\hline \multirow{3}{*}{ Model } & \multicolumn{2}{|c|}{$\begin{array}{c}\text { Unstandardized } \\
\text { Coefficients }\end{array}$} & $\begin{array}{c}\text { Standardized } \\
\text { Coefficients }\end{array}$ & $\mathrm{t}$ & Sig. \\
\hline \multirow{3}{*}{1} & B & $\begin{array}{c}\text { Std. } \\
\text { Error }\end{array}$ & Beta & & \\
\cline { 2 - 8 } & (Constant) & 7.005 & 8,988 & & .779 & .440 \\
\cline { 2 - 7 } & $\begin{array}{c}\text { Principal } \\
\text { Leadership }\end{array}$ & .918 & .074 & .876 & 12,424 & .000 \\
\hline \multicolumn{7}{|c|}{ a. Dependent Variable: Teacher Performance } \\
\hline
\end{tabular}

Then the results of data analysis also show that the $t$ value is 12.424 and the $t$ table value is 2.0129 (Table 1). By comparing the value of $t$ count and $t$ table, it is known that the value of $t_{\text {count }}(12.424)>t_{\text {table }}$ (2.0129), it can be stated that the principal's leadership has a significant effect on teacher performance. With the $\mathrm{R}_{\text {Square }}$ value of 0.767 (Table 2), it means that the increase in teacher performance due to the influence of the principal's leadership is $76.7 \%$.

Table 2 Results of Hypothesis Determinant Coefficient Analysis 1

\begin{tabular}{|c|c|c|c|c|}
\multicolumn{7}{|c|}{ Model Summary } \\
\hline Model & R & R Square & $\begin{array}{c}\text { Adjusted R } \\
\text { Square }\end{array}$ & $\begin{array}{c}\text { Std. Error of } \\
\text { the Estimate }\end{array}$ \\
\hline 1 & $.876 \mathrm{a}$ & .767 & .762 & 2,657 \\
\hline
\end{tabular}

a. Predictors: (Constant), Principal Leadership

\subsection{The Effect of Teacher Work Motivation on Teacher Performance}

The second hypothesis submission is that there is an effect of teacher work motivation on teacher performance. The results of the hypothesis analysis showed that the sig value was 0.000 (Table 3) smaller than the value of $\alpha(0.05)$, while the value of $t_{\text {count }}=$ 14.100 was greater than $t_{\text {table }}=2.0129$; and obtained an $\mathrm{R}$ square value of 0.809 (Table 4). According to these figures, it means that there is an effect of teacher 
work motivation on teacher performance with a contribution of influence reaching $80.9 \%$.

Table 3 Hypothesis Analysis Results 2

\begin{tabular}{|c|c|c|c|c|c|c|}
\hline \multicolumn{7}{|c|}{ Coefficientsa } \\
\hline & \multirow{2}{*}{ Model } & \multicolumn{2}{|c|}{$\begin{array}{l}\text { Unstandardized } \\
\text { Coefficients }\end{array}$} & \multirow{2}{*}{$\begin{array}{c}\text { Standardized } \\
\text { Coefficients } \\
\text { Beta }\end{array}$} & \multirow{2}{*}{$\mathrm{t}$} & \multirow{2}{*}{ Sig. } \\
\hline & & B & $\begin{array}{c}\text { Std. } \\
\text { Error }\end{array}$ & & & \\
\hline \multirow[b]{2}{*}{1} & (Constant) & 5,262 & 8,043 & & .654 & .516 \\
\hline & $\begin{array}{c}\text { Teacher Work } \\
\text { Motivation }\end{array}$ & .949 & .067 & .899 & 14,1 & .000 \\
\hline
\end{tabular}

Table 4 Results of Hypothesis Determinant Coefficient Analysis 2

\begin{tabular}{|c|c|c|c|c|}
\hline \multicolumn{5}{|c|}{ Model Summary } \\
\hline Model & $\mathrm{R}$ & R Square & $\begin{array}{c}\text { Adjusted } \\
\text { R Square }\end{array}$ & $\begin{array}{c}\text { Std. Error } \\
\text { of the } \\
\text { Estimate }\end{array}$ \\
\hline 1 & $.899 \mathrm{a}$ & .809 & .805 & 2,405 \\
\hline
\end{tabular}

3.3 The Influence of Principal Leadership and Teacher Work Motivation on Teacher Performance

The results of multiple linear regression tests analyzed in the $F$ test obtained a significance value smaller than the $\alpha$ value, namely sig $(0.000)<\alpha$ (0.05). The calculated $\mathrm{F}$ value was 135.170 (Table 5); is greater than $F_{\text {table }}=3.20$. So it is concluded that the principal's leadership and teacher work motivation have a significant effect on teacher performance. While RSquare is 0.855 (Table 6). The magnitude of the influence of the two variables on teacher performance reached $85.5 \%$.

Table 5 Hypothesis Analysis Results 3

\begin{tabular}{|c|c|c|c|c|c|c|}
\hline \multicolumn{7}{|c|}{ ANOVAa } \\
\hline $\begin{array}{c}\text { Mode } \\
1\end{array}$ & & $\begin{array}{c}\text { Sum of } \\
\text { Squares }\end{array}$ & df & $\begin{array}{c}\text { Mean } \\
\text { Square }\end{array}$ & $\mathrm{F}$ & Sig. \\
\hline \multirow{3}{*}{1} & $\begin{array}{c}\text { Regressio } \\
n\end{array}$ & $\begin{array}{c}1215,22 \\
3 \\
\end{array}$ & 2 & $\begin{array}{c}607,61 \\
1 \\
\end{array}$ & $\begin{array}{c}135,17 \\
0\end{array}$ & $\begin{array}{c}.000 \\
\mathrm{~b}\end{array}$ \\
\hline & Residual & 206,777 & $\begin{array}{l}4 \\
6\end{array}$ & 4,495 & & \\
\hline & Total & $\begin{array}{c}1422,00 \\
0\end{array}$ & $\begin{array}{l}4 \\
8\end{array}$ & & & \\
\hline
\end{tabular}

a. Dependent Variable: Teacher Performance

b. Predictors: (Constant), Teacher Work Motivation, Principal Leadership

Table 6 Results of Hypothesis Determinant Coefficient Analysis 3

\begin{tabular}{|c|c|c|c|c|}
\hline \multicolumn{5}{|c|}{ Model Summary } \\
\hline Model & $\mathrm{R}$ & R Square & $\begin{array}{c}\text { Adjusted } \\
\text { R Square }\end{array}$ & $\begin{array}{c}\text { Std. Error } \\
\text { of the } \\
\text { Estimate }\end{array}$ \\
\hline 1 & $.924 \mathrm{a}$ & .855 & .848 & 2,120 \\
\hline
\end{tabular}

a. Predictors: (Constant), Teacher Work Motivation, Principal Leadership

This study concludes that principal leadership has a significant effect on teacher performance. Leadership has a contribution to teacher performance [18]. Principal leadership has a direct effect on teacher performance [19]. There is a significant influence between principal leadership on teacher performance [20]. In accordance with the results of data analysis in this study and several other relevant studies above, it can be seen that partially the principal's leadership can affect teacher performance. Leadership plays an important role in improving teacher performance [21], [22]. Therefore, the better a school principal is at leading, the better the teacher's performance will be. If all teachers carry out their duties and functions as educators, educational goals will be achieved maximally.

This study concludes that there is a significant effect of teacher work motivation on teacher performance. This study is similar to several studies conducted by previous researchers which suggested that partially work motivation has a significant effect on teacher performance [23], [24]. This can be proven by the results of different data analysis but still shows the same conclusions.

The higher the work motivation of a teacher, it is certain that the teacher's performance will be better. Conversely, the lower the work motivation of a teacher, the lower the resulting performance. Work motivation is an action taken in order to influence others to be more active when carrying out their work [25], [26]. Teacher work motivation is very important because it can trigger enthusiasm in working in accordance with mutually agreed roles and functions. Teacher work motivation is partially one of the variables that affect teacher performance. All educators should have high work motivation for the success of the learning program and the goals of national education.

This study concludes that principal leadership and teacher work motivation have a significant effect on teacher performance. There is a significant effect of principal leadership and teacher work motivation on teacher performance [27], [28]. The significant and positive influence is evidenced by the acquisition of effective contributions reaching $64.1 \%$. The variables of principal leadership and teacher work motivation are factors that greatly influence teacher performance [29], [30]. Therefore, the leadership spirit of a school principal and its motivation must be considered so that teacher performance can increase. This aims to achieve optimal educational goals

Teacher performance is a condition that shows the professionalism of an educator in carrying out his workload and reflects teacher behavior when in teaching and learning activities. So teacher performance is the result of quality work achieved by a teacher in carrying out duties and responsibilities with the expected results. Performance is sometimes equated with work performance, work effectiveness, work results, goal achievement, work productivity, and so on [31]. Teacher performance is a set of tangible behaviors shown by the teacher when the teacher provides learning to students. Other than that, teacher performance is also an achievement or work result of a teacher who has carried out his duties in a professional manner, namely by presenting all his potential and abilities according to the work standards that have been set. 
Teacher performance is a burden and responsibility that must be carried out and resolved where the teaching staff can show the results of their achievements in accordance with their field of study. One of the determining factors for the success of an educational organization is the teacher staff [32]. Teachers as the main driving force in the field of education, which are expected to advance education. Teachers are also directly related to students, who will guide and provide knowledge that will produce quality generations and produce the expected graduates. Therefore, teacher performance must always be improved, teachers must be able to master the learning process and have good performance. The measure of teacher performance can be seen from the sense of responsibility in carrying out their work as an educator and the profession they carry.

It is expected that the support of quality learning resources can produce superior learning, to increase quality resources. Some of the efforts that are often made to improve teacher performance are providing motivation, incentives, providing opportunities for career development and providing supervision [33], [34]. Presumably a teacher in carrying out the tasks assigned to him can show the best performance. Teacher performance in carrying out their duties is influenced by several factors, namely the leadership of the school principal, work facilities, expectations, personal beliefs and motivation. The factors that influence employee performance are: knowledge, personality, abilities and skills, work design, leadership, leadership style, work motivation, organizational culture, work environment, work discipline, loyalty, commitment, and job satisfaction.

Motivation is the willingness of a person arising from stimuli given by others to be willing to carry out activities or work [35]. Work motivation is closely related to teacher performance. The level of teacher performance can be influenced by work motivation. Teachers as professional educators certainly have different work motivation from one another. This is what can differentiate the results of teacher performance in improving the quality of education.

Motivation is the skill of a leader in exerting all his employees to work as much as possible to achieve organizational goals without neglecting the satisfaction of these employees [36], [37]. Motivation is one of the factors supporting someone to do certain activities. The process of motivation starts from an unsatisfied need, so that there is a feeling of pressure that causes impulses to achieve certain behaviors in the form of efforts. Efforts will produce performance as output and have to do with rewards as results (outcomes) for individual employees, with rewards, the needs are met and pressure will be reduced.

Motivation is a willingness to make every effort to achieve organizational goals in accordance with its ability to satisfy individual needs. Motivation can stimulate the will and become an energy driving one's desire to work. Work motivation is a factor that encourages someone to do certain activities, or it can also be interpreted as a factor driving someone's behavior. Given the heavy tasks that must be done by a teacher, it is only natural for teachers to get many things that can arouse enthusiasm at work. This is very important, because a teacher is expected to produce high performance if he has adequate competence and has good work motivation.

Work motivation is an encouragement that grows from a person, both from within and from outside himself to do a job with high enthusiasm using his abilities and skills [38], [39]. The work motivation of a teacher can be divided into two forms, namely intrinsic motivation and extrinsic motivation. Intrinsic motivation is motivation that arises from within the teacher itself, and is often referred to as pure motivation [40], [41]. While extrinsic motivation is motivation that comes from the outside environment [40], [41]. Extrinsic motivation is divided into two, namely financial and non-financial. Financial motivation is a boost that is done by giving rewards or intensively to a teacher [40], [41]. In contrast to nonfinancial motivation, namely encouragement that is manifested in the form of praise [42], appreciation [43], and other approaches. For example, a teacher is given an honorable position or given an award for work performance obtained [44], [45], and so on.

\section{CONCLUSION}

Based on the results of data processing, it is concluded that: (1) the principal's leadership has a significant effect on teacher performance; (2) teacher work motivation also has a significant effect on teacher performance; and (3) principal leadership and teacher work motivation have a significant and positive effect on teacher performance. To encourage the leadership spirit of a school principal and teacher work motivation in improving teacher performance in the future, the principal should improve his ability to lead, motivate teachers, and foster teachers in order to improve their professional performance. Teachers must be able to increase their work motivation through concrete actions, such as obeying and implementing working hour regulations, making detailed classroom administration,

\section{ACKNOWLEDGMENTS}

Thank you to the principal and teachers who have helped in collecting research data. Thank to the Rector, the Director of the Postgraduate Program, and the Head of the Educational Management at the Universitas PGRI Palembang, who has provided guidance in writing this article.

\section{REFERENCES}

[1] S. Ahmad, "Ketahanmalangan Kepemimpinan Kepala Sekolah: Salah Satu Faktor Penentu 
Keberhasilan Kepala Sekolah". Yogyakarta: Pustaka Felicha, 2016.

[2] K. Apriyanti, "Pengaruh Kepemimpinan Kepala Sekolah dan Motivasi Kerja terhadap Kinerja Guru (Studi Kasus di Sekolah Dasar se-Kecamatan Bojongsoang Kabupaten Bandung)". Bandung: Universitas Widyatama, 2014.

[3] Arafat, "Pengaruh Kepemimpinan Kepala Sekolah dan Partisipasi Komite Sekolah terhadap Kinerja Guru”. JMKSP, Vol. 5 No. 2, 2020.

[4] Arafat, "Pengaruh Komitmen Organisasi dan Motivasi Kerja terhadap Kinerja Guru". JMKSP, Vol. 6, No. 1, 2021.

[5] V. Arimbi, "Pengaruh Kepemimpinan Kepala Sekolah terhadap Kinerja Guru Sekolah Menengah Kejuruan (SMK) Negeri di Temanggung”. Yogyakarta: UNY, 2011.

[6] F. Asterina, and Sukoco, "Pengaruh Kepemimpinan Kepala Sekolah, Motivasi Kerja, dan Disiplin Guru terhadap Kinerja Guru". Jurnal Akuntabilitas Manajemen Pendidikan, Vol. 7, No. 2, p. 208-219, 2019.

[7] M. Cholil, "Pengaruh Kepemimpinn Kepala Sekolah dan Motivasi Kerja terhadap Kinerja Guru di SMP Muhammadiyah Ngawi”. Media Prestasi. Jurnal Ilmiah STKIP PGRI Ngawi.

[8] Eddy, "Pengaruh Kepemimpinan Kepala Sekolah dan Motivasi Kerja terhadap Kinerja Guru". Jounal of Innovation in Teaching and Instruction Media. Palembang: UPGRI.

[9] Engkoswara, and A. Komariah, "Administrasi Pendidikan". Bandung: Alfabeta, 2010.

[10] N. Fattah, "Landasan Manajemen Pendidikan". Bandung: PT. Remaja Rosdakarya, 2006.

[11] H. A. Fattah, "Kepuasan Kerja dan Kinerja Pegawai". Yogyakarta: Elmatera, 2019.

[12] M. S. Hasibuan, "Manajemen Sumber Daya Manusia”. Jakarta: Bumi Aksara, 2009.

[13] T. Ismail, "Kepemimpinan, Kompetensi, Motivasi Kerja, dan Kinerja Guru SD Negeri”. Jurnal Administrasi Pendidikan, Vol. 24, No. 1, p. 60-69, 2017.

[14] I. Gunawan, "Metode Penelitian Kuantitatif". Retrieved June 7, 2019, from http://fip.um.ac.id/wpcontent/uploads/2015/12/2_MetpenKuantitatif.pdf.

[15] I. Gunawan, "Pengantar Statistika Inferensial". Jakarta: Rajawali Pers, 2016.

[16] I. Gunawan, "Statistika untuk Kependidikan Sekolah Dasar". Yogyakarta: Penerbit Ombak Yogyakarta, 2013.

[17] I. Gunawan, "Introduction to inferential statistics”. Jakarta: PT Raja Grafindo Persada, 2016.

[18] M. Kristiawan, M. Manajemen Pendidikan. Yogyakarta: Deepublish, 2017.
[19] B. Lian, "The Influence of Principal Supervision and Organizational Climate toward Teacher's Performance". Electronic Research Journal of Social Sciences and Humanities, Vol 2, Issue II, 2020.

[20] A. Malik, and Sriwidodo, "Pengaruh Motivasi Kerja dan Kedisiplinan terhadap Kinerja Guru SMA Asslaam Surakarta dengan Kepemimpinan Kepala Sekolah sebagai Variabel Moderasi". Jurnal Manajemen Sumber Daya Manusia, 2013.

[21] E. Mulyasa, "Menjadi Guru Profesional Menciptakan Pembelajaran Kreatif dan Menyenangkan". Bandung: Remaja Rosdakarya, 2004.

[22] E. Mulyasa, "Menjadi Kepala Sekolah yang Profesional". Bandung: Remaja Rosdakarya, 2013.

[23] Murniyati, "Pengaruh Kepemimpinan Kepala Sekolah dan Motivasi Kerja terhadap Kinerja Guru SMA PGRI di Kota Palembang". Tesis, UPGRI Palembang, 2019.

[24] S. Ngiode, "Pengaruh Kepemimpinan Kepala Sekolah, Motivasi Kerja dan Disiplin Kerja terhadap Kinerja Guru MTsN Batudaa Kabupaten Gorontalo. Tadbir: Jurnal Manajemen Pendidikan Islam, 2016.

[25] R. Palupi, "Pengaruh Kepemimpinan Kepala Sekolah dan Motivasi Kerja Guru terhadap Kinerja Guru Sekolah Dasar Negeri Gugus Wiratno Kecamatan Cilacap Tengah. Semarang: UNS, 2016.

[26] P. Prawira, "Psikologi Pendidikan dalam Perspektif Baru". Yogyakarta: Ar-Ruzz Media, 2013.

[27] Pudjiastuti, "Pengaruh Kompetensi, Disiplin Kerja, dan Kepuasan Kerja terhadap Kinerja Guru SMP Negeri 1 Purwodadi Grobokan. Jurnal Manajemen Sumber Daya Manusia, 2011.

[28] R. Purnama, "Pengaruh Motivasi Kerja terhadap Produktifitas Kerja Karyawaan pada Bagian Produksi CV. Epsilon Bandung. Journal Strategic, 2008.

[29] A. T. Rahardja, "Hubungan Antara Komunikasi antara Pribadi Guru dan Motivasi Kerja Guru dengan Kinerja Guru SMUK Penabur Jakarta. Jurnal Pendidikan Penabur III, 2014.

[30] S. Rahayu, "Kepemimpinan Kepala Sekolah dan Kedisiplinan Guru SMPN Kota Surakarta. Jurnal Manajemen Pendidikan, 2014.

[31] Riduwan, "Skala Pengukuran Variabel-variabel Penelitian". Bandung: Alfabeta, 2010.

[32] V. Rivai, "Kepemimpinan dan Perilaku Organisasi”. Jakarta: Raja Grafindo Persada, 2005.

[33] Sepriyadi, and A. Syarwani, "Pengaruh Peran Kepala Sekolah sebagai Supervisor Akademik terhadap Kinerja Guru di SMA PGRI Tanjung 
Raja. Jurnal Manajemen, Kepemimpinan, dan Supervisi Pendidikan, JMKSP, Vol. 2, No. 1, 2017.

[34] S. Setiyati, "Pengaruh Kepemimpinan Kepala Sekolah, Motivasi Kerja, dan Budaya Sekolah terhadap Kinerja Guru". Jurnal pendidikan Teknologi dan Kejuruan, Vol. 22, No. 2, p. 200-206, 2014.

[35] U. Sriwidodo, adn A. B. Haryanto, "Pengaruh Kompetensi, Motivasi, Komunikasi dan Kesejahteraan terhadap Kinerja Pegawai Dinas Pendidikan. Jurnal Manajemen Sumber Daya Manusia, 2010.

[36] Sukardi, "Metodologi Penelitian Pendidikan, Kompetensi dan Praktiknya. Jakarta: Bumi Aksara, 2008.

[37] Sule, and Kurniawan, "Pengantar Manajemen". Jakarta: PT. Raja Grafindo Persada, 2006.

[38] Syakir, and Pardjono, "Pengaruh Kepemimpinan Kepala Sekolah, Motivasi Kerja dan Budaya Organisasi terhadap Kompetensi Guru SMA. Jurnal Akuntabilitas Manajemen Pendidikan, 2015.

[39] C. Wijaya, and A. T. Rusyan, "Kemampuan Dasar Guru dalam Proses Belajar Mengajar. Bandung: Rosdakarya, 2000.

[40] M. Yamin, and Maisah, "Standarisasi Kinerja Guru”. Jakarta: Gaung Persada Press, 2010.

[41] Yuliandri, "Peran Kepemimpinan Kepala Sekolah terhadap Peningkatan Kinerja Guru”.
Prosiding seminar Naional Pendidikan Mewujudkan Sumber Daya Manusia yang Profesional dalam Kompetisi Global, Program Pascasarjana Universitas PGRI Palembang, 2016.

[42] N. Y. Rizky, I. Gunawan, and A. D. Wardani, "Compensation and Performance of Educators in Schools: A Qualitative Study". In 6th International Conference on Education and Technology (ICET 2020) (pp. 259-263), Atlantis Press, 2020.

[43] N. O. Yulindasari, A. Kusna, B. A. Mahardika, D. R. Nugraheni, D. Eriyani, S. Taftania, ... \& I. Gunawan, "Principal's Visionary Leadership in the Framework of School Change Process". In 1st International Conference on Information Technology and Education (ICITE 2020) (pp. 477-483), Atlantis Press, 2020.

[44] S. O. Ningsih, and I. Gunawan, "Relationship of Self-Efficiency and School Climate With Teacher Work Motivation". In 6th International Conference on Education and Technology (ICET 2020) (pp. 342-345), Atlantis Press, 2020.

[45] B. A. Pambudi, and I. Gunawan, "The Effect of Learning Leadership, Academic Supervision, and Teacher Skills on Teacher Performance Effectiveness". In 1st International Conference on Information Technology and Education (ICITE 2020) (pp. 1-4), Atlantis Press, 2020. 